ISSN 1678-3921

Journal homepage: www.embrapa.br/pab

For manuscript submission and journal contents, access: www.scielo.br/pab

\section{Performance of lightweight replacement pullets fed rations with sunflower cake and the addition of enzymes}

\begin{abstract}
The objective of this work was to evaluate the inclusion of sunflower cake (SC) and the addition of enzymes in the ration of lightweight replacement pullets in the growth phase, as well as their effects on the variables feed consumption and conversion, productive performance, sexual maturity, egg quality at the beginning of the laying phase, and economic viability. Five hundred and forty pullets of the Hy-Line W-36 light line were used. The experimental design was completely randomized, in a $2 \times 2+1$ factorial arrangement, with two inclusion levels of SC (10 and 20\%), with or without the addition of enzymes, and a control treatment. At the end of the growth phase ( 7 to 17 weeks age), 360 birds were transferred to the laying shed until their thirty-fifth week of age. There was no interaction between SC levels and enzymes, but an isolated effect of rations and enzymes was observed on feed consumption and conversion. There was a decrease in specific egg density and an interaction between the factors for this variable, but without affecting productive performance. The inclusion of up to $20 \% \mathrm{SC}$ in the rations does not affect bird performance in both evaluated phases; however the use of $20 \% \mathrm{SC}$ with enzymes is more economically viable.
\end{abstract}

Index terms: Helianthus annuиs, alternative feedstuff, egg quality, exogenous enzymes.

\section{Desempenho de frangas de reposição leves alimentadas com ração com torta de girassol e adição de enzimas}

Resumo - O objetivo deste trabalho foi avaliar a inclusão de torta de girassol (TG) e a adição de enzimas nas rações de frangas de reposição leves, em fase de crescimento, bem como seus efeitos sobre as variáveis consumo e conversão alimentar, desempenho produtivo, maturidade sexual, qualidade dos ovos no início da fase de postura e viabilidade econômica. Foram utilizadas 540 frangas da linhagem leve Hy-Line W-36. O delineamento experimental foi inteiramente casualizado, em arranjo fatorial $2 \times 2+1$, com dois níveis de inclusão de TG (10 e 20\%), com ou sem adição de enzimas, mais um controle. Ao final da fase de crescimento ( 7 a 17 semanas de idade), 360 aves foram transferidas para o galpão de postura até a trigésima quinta semana de idade. Não houve interação entre os níveis de TG e as enzimas, mas observou-se efeito isolado das rações e das enzimas sobre o consumo e a conversão alimentar. Houve diminuição da densidade específica dos ovos e interação entre os fatores para essa variável, mas sem afetar o desempenho produtivo. A inclusão de até $20 \%$ de TG nas rações não afeta o desempenho em ambas as fases avaliadas; no entanto, o uso de $20 \%$ de TG com enzimas é mais economicamente viável.

Termos para indexação: Helianthus annuus, alimento alternativo, qualidade dos ovos, enzimas exógenas. 


\section{Introduction}

An adequate nutrition in the growth phase is a fundamental factor in the production of commercial laying hens, which, to reach sexual maturity, require the right nutrients for a good body development, feathering, and the formation of their reproductive apparatus, avoiding a reduction in their growth (Braz et al., 2011).

However, to provide the nutritional requirement of these birds, high standard ingredients, with high costs, are commonly used, which may reduce the producer's profit margin. Therefore, some alternative rations have been tested to replace the traditional ones, without affecting animal performance and the quality of the final product (Arruda et al., 2016).

One of the used ingredients is the sunflower cake, derived from the extraction of oil from the plant - by pressing seeds with shells and without using solvents -, which has been increasing due to the oil's excellent quality for human consumption (Bacaxixi et al., 2011) and potential for biodiesel production (Oliveira et al., 2012).

The sunflower cake has been used in bird feeding due to its interesting chemical and energetic composition, with approximate contents of 22.33 to $28.44 \%$ crude protein and 2,150 to $3,056 \mathrm{kcal} \mathrm{kg}^{-1}$ apparent metabolizable energy corrected for nitrogen retention (EMAn) (Pereira et al., 2011; Oliveira et al., 2012; Pinheiro et al., 2013; Berwanger et al., 2014).

However, some factors may limit the use of the sunflower cake in bird feeding, such as its high fiber content and the presence of phytates and chlorogenic acid (Berwanger et al., 2014; Andrade et al., 2015). According to Jacob et al. (1996), the insoluble fiber content of sunflower cake may be considered the main limiting factor for its use in the feeding of nonruminant animals.

To minimize the possible harmful effects of the use of sunflower cake in bird feed due to fiber and antinutritional factors, such as chlorogenic acid and phytates, exogenous enzymes have been added, in order to hydrolyze carbohydrates, proteins and phytic phosphorus, favoring their use (Barbosa et al., 2014) mainly in the growth phase in which the organs of pullets are in development and show little efficiency in the secretion of endogenous enzymes (Opalinski et al., 2010).
Few studies have been carried out using sunflower cake with growing hens. Pinheiro et al. (2013), for example, tested inclusion levels of up to $21 \%$ sunflower cake in the rations of semi-heavy laying hens during growing and production, and observed that animal performance was not hindered up to this level. However, more research is necessary to verify the effectiveness of enzymes in improving the capacity of growing pullets to use nutrients from rations containing sunflower cake, without negatively affecting the production phase.

The objective of this work was to evaluate the inclusion of sunflower cake (SC) and the addition of enzymes in the ration of lightweight replacement pullets in the growth phase, as well as their effects on the variables feed consumption and conversion, productive performance, sexual maturity, egg quality at the beginning of the laying phase, and economic viability.

\section{Materials and Methods}

The experiment was carried out at the sector of poultry industry of the Department of Animal Science of Universidade Federal do Ceará (UFC), located in the municipality of Fortaleza, in the state of Ceará, Brazil, from 6/20/2016 to $1 / 9 / 2017$, totaling a breeding period of 35 weeks. The experimental protocols were approved by the ethics committee on animal use of UFC on $9 / 22 / 2017$.

The experimental design was completely randomized, in a $2 \times 2+1$ factorial arrangement, with 10 and $20 \%$ inclusion of sunflower cake $\times$ with or without the addition of an enzymatic complex + a control treatment based on corn (Zea mays L.) and soybean [Glycine $\max (\mathrm{L}$.$) Merr.] meal, totaling five treatments$ with six replicates of 18 birds.

A total of 900 one-day-old chicks of the Hy-Line W-36 light line were acquired and were housed in a conventional shed, where they were managed according to the Management Guide (Hy-Line International, 2016) for the line until the sixth week of age. At the end of this week, the birds were weighed individually and selected based on body weight $(451 \pm 11.95 \mathrm{~g})$ to obtain homogeneous plots (Sakomura \& Rostagno, 2007).

For the experiment in the growth phase from 7 to 17 weeks of age, 540 pullets were used and placed in a conventional shed for growing poultry, which contained galvanized wire cages $(50 \mathrm{~cm}$ in length $\mathrm{x}$ 
$50 \mathrm{~cm}$ in width $\mathrm{x} 45 \mathrm{~cm}$ in height), with trough-type feeders and nipple-type water drinkers, with a housing density of $416 \mathrm{~cm}^{2}$ per bird.

Vaccination was carried out based on a program elaborated according to the sanitary situation of the region. The birds were immunized with vaccines against: Newcastle disease, developed with the HB1 virus; bronchitis, with the H120 virus; Gumboro, with the intermediate strain; coryza, with aluminumhydroxide adjuvant; coryza, with mineral-oil adjuvant; avian poxvirus, with the strong strain; and egg drop syndrome.

Birds were debeaked by the conventional method at seven days of age and redebeaked at the twelfth week of age.

The diets were formulated based on the nutritional requirements described in the Management Guide (Hy-Line International, 2016) and on the energetic and nutritional values of each ingredient (corn, soybean meal, and soybean oil) according to Rostagno (2017).

The SC was obtained from sunflower seeds with shells by the mechanical pressing method for oil removal, using the ERT 40-V1 mechanical press (Scott Tech Equipamentos, Vinhedo, SP, Brazil). The SC nutritional composition was determined in the Laboratory of Animal Nutrition of the Department of Animal Science of UFC, using the method described by Silva \& Queiroz (2002), whereas metabolizable energy was obtained from the total collection of excreta in a previous metabolism assay (Sakomura \& Rostagno, 2007).

The nutritional composition obtained was: $92.81 \%$ dry matter, 2,774 kcal kg-1 EMAn, $19.35 \%$ crude protein, $15.52 \%$ ethereal extract, $43.95 \%$ neutral detergent fiber, $28.96 \%$ acid detergent fiber, and $2.66 \%$ mineral matter. The values of $0.28 \%$ calcium, $0.09 \%$ available phosphorus, $0.03 \%$ sodium, $0.08 \%$ chlorine, $1.16 \%$ potassium, $0.59 \%$ digestible lysine, $0.59 \%$ digestible methionine, $0.68 \%$ methionine + digestible cystine, $0.61 \%$ digestible threonine, and $0.22 \%$ digestible tryptophan were estimated according to the tables of Fundación Española para el Desarrollo de la Nutrición Animal (FEDNA, 2010) and expressed in natural matter.

The enzyme complex consisted of: carbohydrases, such as $\alpha$-galactosidase, xylanase, and $\beta$-glucanase; proteases, alkaline serum enzymes that act analogously to trypsin, chymotrypsin, and elastase proteins; and phytases, whose indicated quantity for each enzymatic matrix was $100 \mathrm{~g} \mathrm{Mg}^{-1}$ ration. Enzymes contributed with $104,000 \mathrm{kcal} \mathrm{kg}^{-1}$ in metabolizable energy and $0.901 \%$ in crude protein, besides with amino acids, calcium, phosphorus and sodium, which leads to a reduction in the values of the nutritional matrix.

Temperature and relative air humidity were measured daily with the aid of the HOBO U12-012 data logger (Onset Computer Corporation, Bourne, MA, USA). Data readings were performed at 8:00 a.m. and 4:00 p.m. The minimum and maximum average ambient temperatures and relative humidity recorded were: $26.82^{\circ} \mathrm{C} \pm 0.73,30.40^{\circ} \mathrm{C} \pm 1.84$, and $64 \%$, respectively, for the growth phase, and $26.83 \pm 0.62,31.08 \pm 1.78$, and $59 \%$, respectively, for the laying phase.

The feeding program was divided into two phases (Tables 1 and 2): from 7 to 12 weeks of age for breeding; and from 13 to 17 weeks for rearing. However, performance was analyzed in the total growth phase of 7 to 17 weeks of age, when the variables of feed consumption (gram per bird), final average weight (gram per bird), weight gain (gram per bird), and feed conversion $\left(\mathrm{g} \mathrm{g}^{-1}\right)$ were assessed. For calculations, birds and the rations were weighed at the beginning and end of the experimental period.

To study the economic feasibility of including SC and enzymatic complexes in bird feed, the cost of the ration was initially determined in Brazilian real per kilogram of body weight gain ( $\mathrm{R} \$ \mathrm{~kg}^{-1}$ weight gain), adapting the equation proposed by Bellaver et al. (1985). The equation proposed by Fialho et al. (1992) was used to calculate the economic efficiency index $(\%)$ and the cost index (\%).

At the end of the seventeenth week of age, 360 birds were transferred to the laying shed, where the same experimental design was maintained. During this phase, the birds were distributed in galvanized wire cages (25 $\mathrm{cm}$ long $\times 45 \mathrm{~cm}$ wide $\times 40 \mathrm{~cm}$ high), equipped with a linear feeder and nipple-type drinkers, by allocating two birds per cage $\left(563 \mathrm{~cm}^{2}\right.$ per bird). The experimental period in this phase extended up to the thirty-fifth week of age of the birds, divided into six periods of 21 days each. During this period, only one kind of ration was offered, at will, to all birds, based on corn and soybean meal, containing $2,900 \mathrm{kcal} \mathrm{kg}^{-1}$ metabolizable energy and $16 \%$ crude protein, considering the food composition values proposed by Rostagno (2017) and 
the requirements described in the Management Guide (Hy-Line International, 2016).

The initial lighting at this stage was 14 hours of light per day. From the following week onwards, there was

Table 1. Composition and nutritional and energetic levels of the experimental ration with or without the inclusion of sunflower cake (SC) and the addition of enzymes (ENZ) for Hy-Line W-36 pullets in the breeding period from 7 to 12 weeks of age.

\begin{tabular}{|c|c|c|c|c|c|}
\hline Ingred & $\begin{array}{l}0 \% \\
\mathrm{SC}\end{array}$ & $\begin{array}{l}10 \% \\
\mathrm{SC}\end{array}$ & $\begin{array}{c}20 \% \\
\mathrm{SC}\end{array}$ & $\begin{array}{c}10 \% \mathrm{SC} \\
+\mathrm{ENZ}\end{array}$ & $\begin{array}{l}20 \% \mathrm{SC} \\
+\mathrm{ENZ}\end{array}$ \\
\hline Corn & 65.41 & 61.16 & 53.33 & 63.70 & 58.33 \\
\hline Soybean meal & 26.97 & 23.32 & 20.32 & 20.93 & 17.50 \\
\hline Sunflower cake & 0.00 & 10.00 & 20.00 & 10.00 & 20.00 \\
\hline Soybean oil & 1.90 & 1.53 & 2.36 & 0.00 & 0.00 \\
\hline Enzymatic complex & 0.00 & 0.00 & 0.00 & 0.03 & 0.03 \\
\hline Limestone & 1.12 & 1.07 & 1.02 & 1.14 & 1.09 \\
\hline Bicalcium phosphate & 2.01 & 2.01 & 2.03 & 1.28 & 1.29 \\
\hline Common salt & 0.38 & 0.38 & 0.38 & 0.30 & 0.30 \\
\hline Mineral/vitamin premix ${ }^{(1)}$ & 0.20 & 0.20 & 0.20 & 0.20 & 0.20 \\
\hline DL-methionine & 0.19 & 0.17 & 0.16 & 0.13 & 0.12 \\
\hline L-lysine HCL & 0.09 & 0.15 & 0.19 & 0.16 & 0.21 \\
\hline L-threonine & 0.00 & 0.01 & 0.02 & .00 & 0.00 \\
\hline Inert $^{(2)}$ & 1.72 & 0.00 & 0.00 & 12 & 0.93 \\
\hline Total & 100.0 & 100.0 & 100.0 & 100.0 & 100.0 \\
\hline Cost $\left(\mathrm{R} \$ \mathrm{~kg}^{-1}\right)$ & 1.52 & 1.47 & 1.43 & 1.40 & 1.35 \\
\hline & \multicolumn{5}{|c|}{ Calculated nutritional composition } \\
\hline $\begin{array}{l}\text { Metabolizable energy } \\
\left(\mathrm{kcal} \mathrm{kg}^{-1}\right)\end{array}$ & 3.000 & 3.000 & 3.000 & 2.896 & 2.896 \\
\hline Crude protein $(\%)$ & 17.55 & 17.55 & 17.55 & 16.65 & 16.65 \\
\hline Dry matter $(\%)$ & 88.73 & 88.99 & 89.58 & 88.96 & 89.39 \\
\hline Acid detergent fiber $(\%)$ & 4.38 & 7.91 & 11.36 & 7.80 & 11.31 \\
\hline Neutral detergent fiber $(\%)$ & 11.52 & 16.80 & 21.75 & 16.78 & 21.96 \\
\hline Calcium (\%) & 1.00 & 1.00 & 1.00 & 0.84 & 0.84 \\
\hline Available phosphorus (\%) & 0.47 & 0.47 & 0.47 & 0.33 & 0.33 \\
\hline Sodium $(\%)$ & 0.17 & 0.17 & 0.17 & 0.14 & 0.14 \\
\hline Chlorine (\%) & 0.28 & 0.28 & 0.28 & 0.23 & 0.23 \\
\hline Potassium (\%) & 0.68 & 0.72 & 0.75 & 0.68 & 0.72 \\
\hline Digestible methionine (\%) & 0.43 & 0.43 & 0.43 & 0.38 & 0.38 \\
\hline $\begin{array}{l}\text { Methionine }+ \\
\text { digestible cystine (\%) }\end{array}$ & 0.68 & 0.68 & 0.68 & 0.62 & 0.62 \\
\hline Digestible lysine (\%) & 0.89 & 0.89 & 0.89 & 0.84 & 0.84 \\
\hline Digestible threonine (\%) & 0.60 & 0.60 & 0.60 & 0.56 & 0.55 \\
\hline Digestible tryptophan (\%) & 0.18 & 0.18 & 0.18 & 0.17 & 0.17 \\
\hline
\end{tabular}

${ }^{(1)}$ Guarantee levels per kilogram of product: 5,500,000 IU vitamin A, $500 \mathrm{mg}$ vitamin $\mathrm{B} 1,7,500 \mathrm{mg}$ vitamin $\mathrm{B} 12,2,502 \mathrm{mg}$ vitamin $\mathrm{B}, 750$ $\mathrm{mg}$ vitamin $\mathrm{B} 6,1,000,000 \mathrm{IU}$ vitamin $\mathrm{D} 3,6,500 \mathrm{IU}$ vitamin $\mathrm{E}, 1,250$ $\mathrm{mg}$ vitamin K3, $25 \mathrm{mg}$ biotin, $17.5 \mathrm{~g}$ niacin, $251 \mathrm{mg}$ folic acid, $6.030 \mathrm{mg}$ pantothenic acid, $50 \mathrm{mg}$ cobalt, $3,000 \mathrm{mg}$ copper, $25 \mathrm{~g}$ iron, $500 \mathrm{mg}$ iodine, $32.5 \mathrm{~g}$ manganese, $100.05 \mathrm{mg}$ selenium, and $22.49 \mathrm{~g}$ zinc. ${ }^{(2)}$ Washed sand. an increase of 15 min of light per day until reaching 16 hours of light per day, which was maintained up to the end of the experiment.

Table 2. Composition and nutritional and energy levels of the experimental ration with or without the inclusion of sunflower cake (SC) and the addition of enzymes (ENZ) for Hy-Line W-36 pullets in the rearing period from 13 to 17 weeks of age.

\begin{tabular}{lccccc}
\hline Ingredients (kg) & $0 \%$ & $10 \%$ & $20 \%$ & $10 \% \mathrm{SC}$ & $20 \% \mathrm{SC}$ \\
& $\mathrm{SC}$ & $\mathrm{SC}$ & $\mathrm{SC}$ & $+\mathrm{ENZ}$ & $+\mathrm{ENZ}$ \\
\hline Corn & 71.95 & 66.59 & 59.51 & 64.63 & 59.27 \\
Soybean meal & 22.59 & 19.15 & 16.03 & 17.57 & 14.14 \\
Sunflower cake & 0.00 & 10.00 & 20.00 & 10.00 & 20.00 \\
Soybean oil & 0.00 & 0.00 & 0.58 & 0.00 & 0.00 \\
Enzymatic complex & 0.00 & 0.00 & 0.00 & 0.03 & 0.03 \\
Limestone & 1.20 & 1.14 & 1.09 & 1.21 & 1.15 \\
Bicalcium phosphate & 1.93 & 1.94 & 1.95 & 1.21 & 1.22 \\
Common salt & 0.41 & 0.40 & 0.40 & 0.33 & 0.33 \\
Mineral/vitamin premix ${ }^{(1)}$ & 0.20 & 0.20 & 0.20 & 0.20 & 0.20 \\
DL-methionine & 0.13 & 0.12 & 0.10 & 0.08 & 0.06 \\
L-lysine HCL & 0.04 & 0.09 & 0.14 & 0.09 & 0.14 \\
L-threonine & 0.00 & 0.00 & 0.00 & 0.00 & 0.00 \\
Inert ${ }^{2)}$ & 1.56 & 0.37 & 0.00 & 4.66 & 3.47 \\
Total & 100.0 & 100.0 & 100.0 & 100.0 & 100.0 \\
Cost (R\$ kg-1) & 1.44 & 1.39 & 1.35 & 1.32 & 1.27 \\
\hline & $\mathrm{Calculated}$ & nutritional composition \\
Metabolizable energy & 2.950 & 2.950 & 2.950 & 2.846 & 2.846 \\
(kcal kg-1) & 16.00 & 16.00 & 16.00 & 15.10 & 15.10 \\
Crude protein (\%) & 88.41 & 88.78 & 89.30 & 89.11 & 89.48 \\
Dry matter (\%) & 4.25 & 7.75 & 11.23 & 7.56 & 11.07 \\
Acid detergent fiber (\%) & 11.69 & 16.88 & 21.90 & 16.42 & 21.61 \\
Neutral detergent fiber (\%) & 1.00 & 1.00 & 1.00 & 0.84 & 0.84 \\
Calcium (\%) & 0.45 & 0.45 & 0.45 & 0.31 & 0.31 \\
Available phosphorus (\%) & 0.18 & 0.18 & 0.18 & 0.15 & 0.15 \\
Sodium (\%) & 0.29 & 0.29 & 0.29 & 0.25 & 0.25 \\
Chlorine (\%) & 0.62 & 0.65 & 0.69 & 0.62 & 0.66 \\
Potassium (\%) & 0.36 & 0.36 & 0.36 & 0.31 & 0.31 \\
Digestible methionine (\%) & & & & & \\
Methionine + & 0.59 & 0.59 & 0.59 & 0.52 & 0.52 \\
digestible cystine (\%) & & & & & \\
Digestible lysine (\%) & 0.75 & 0.75 & 0.75 & 0.70 & 0.70 \\
Digestible threonine (\%) & 0.54 & 0.54 & 0.53 & 0.51 & 0.50 \\
Digestible tryptophan (\%) & 0.16 & 0.16 & 0.16 & 0.15 & 0.15 \\
\hline
\end{tabular}

${ }^{(1)}$ Guarantee levels per kilogram of product: 5,500,000 IU vitamin A, $500 \mathrm{mg}$ vitamin $\mathrm{B} 1,7,500 \mathrm{mg}$ vitamin $\mathrm{B} 12,2,502 \mathrm{mg}$ vitamin $\mathrm{B}, 750$ $\mathrm{mg}$ vitamin $\mathrm{B} 6,1,000,000$ IU vitamin $\mathrm{D} 3,6,500 \mathrm{IU}$ vitamin $\mathrm{E}, 1,250$ $\mathrm{mg}$ vitamin $\mathrm{K} 3,25 \mathrm{mg}$ biotin, $17.5 \mathrm{~g}$ niacin, $251 \mathrm{mg}$ folic acid, $6.030 \mathrm{mg}$ pantothenic acid, $50 \mathrm{mg}$ cobalt, 3,000 $\mathrm{mg}$ copper, $25 \mathrm{~g}$ iron, $500 \mathrm{mg}$ iodine, $32.5 \mathrm{~g}$ manganese, $100.05 \mathrm{mg}$ selenium, and $22.49 \mathrm{~g}$ Zinc. ${ }^{(2)}$ Washed sand. 
The performance variables evaluated in the production phase were: percentage of posture (\%), feed consumption in grams per bird per day, egg weight in grams, egg mass in grams per bird per day, feed conversion per egg mass ratio in $\mathrm{g} \mathrm{g}^{-1}$, and sexual maturity as average age at first egg in days. The egg production of each replicate was counted daily; for this, the eggs were separated in trays properly identified per plot and then weighed on the ARA520 scale with an accuracy of $0.01 \mathrm{~g}$ (Ohaus Corporation, Pine Brook, NJ, USA).

Three eggs from each plot were selected according to their mean weight, in order to assess egg quality (specific density in $\mathrm{g} \mathrm{cm}^{-3}$ and Haugh units) and characteristics (percentages of yolk, eggshell, and albumen).

The analysis of the data was performed using the SAS software (SAS Institute Inc., Cary, NC, USA) through the analysis of variance (Anova) procedure, in a $2 \times 2+1$ factorial arrangement model. The averages of the factors were compared by the F-test, at 5\% probability, and the averages of each treatment in isolation were compared with the control treatment by Dunnett's test, also at $5 \%$ probability.

\section{Results and Discussion}

There was no interaction between the SC inclusion levels and enzymes for the evaluated performance variables (Table 3). However, the use of enzymes affected the feed intake and conversion of the studied rations. The birds consumed a greater amount of ration in the treatments containing 10 and $20 \%$ SC with enzymes, compared with the control treatment, which reduced feed conversion, but did not affect the final average weight and weight gain of the animals. Rations with $20 \%$ SC and with enzymes increased feed consumption by birds, while feed conversion was worse when enzymes were added to the rations. The increase in feed consumption when including $20 \%$ $\mathrm{SC}$ can be justified by the high insoluble fiber content present in the SC (Kalmendal et al., 2011), which tends to increase motility, decreasing the action of the digestive enzymes in the digestive tract, and also to increase nutrient passage rate and digestibility, which makes it difficult for the digestive enzymes to access nutrients during digestion (Oliveira et al., 2014).
The negative effect of the inclusion of enzymes in the ration on feed conversion can be justified by the reduction in the amount of lipids in the ration with the addition of enzymes. Moreover, rations with $20 \%$ SC have more than $5.0 \%$ fat due to the amount of soybean oil and fat in them, while those with enzymes present 1.5 and $3.0 \%$ fat. This caused the birds to increase feed intake, and, since their weight was not affected, there was a worsening in feed conversion.

Pinheiro et al. (2013) evaluated semi-weight growing pullets from their tenth to sixteenth week of age, by including $0,7,14$, and $21 \%$ sunflower cake, without enzymes, in the rations. Similarly to the observed in the present study (Table 3), the authors did not find significant effects on the variables weight gain and feed consumption and conversion.

Table 3. Performance of Hy-line W-36 pullets during the total growth period from 7 to 17 weeks, when fed with ration with or without the inclusion of sunflower cake (SC) and the addition of enzymes (ENZ) ${ }^{(1)}$.

\begin{tabular}{|c|c|c|c|c|}
\hline \multirow[t]{2}{*}{ Ration } & \multicolumn{4}{|c|}{ Variable $^{(2)}$} \\
\hline & $\begin{array}{l}\mathrm{FC} \\
(\mathrm{g})\end{array}$ & $\begin{array}{c}\text { FAW } \\
(\mathrm{g})\end{array}$ & $\begin{array}{l}\text { WG } \\
(\mathrm{g})\end{array}$ & $\begin{array}{c}\mathrm{FC} \\
\left(\mathrm{g} \mathrm{g}^{-1}\right)\end{array}$ \\
\hline $0 \% \mathrm{SC}$ & $3,428.82$ & $1,180.11$ & 726.45 & 4.71 \\
\hline $10 \% \mathrm{SC}$ & $3,459.32$ & $1,171.67$ & 717.04 & 4.82 \\
\hline $20 \% \mathrm{SC}$ & $3,530.83$ & $1,171.11$ & 730.47 & 4.83 \\
\hline $10 \% \mathrm{SC}+\mathrm{ENZ}$ & $3,615.36^{*}$ & $1,184.78$ & 735.92 & $4.93^{*}$ \\
\hline $20 \% \mathrm{SC}+\mathrm{ENZ}$ & $3,692.02 *$ & $1,172.89$ & 728.81 & $5.06^{*}$ \\
\hline Average & $3,545.27$ & $1,176.11$ & 727.14 & 4.87 \\
\hline \multirow[t]{2}{*}{ CV (\%) } & 2.33 & 1.48 & 2.68 & 2.00 \\
\hline & \multicolumn{4}{|c|}{ Level } \\
\hline $10 \%$ & $3537.34 \mathrm{~b}$ & $1,178.22$ & 724.98 & 4.88 \\
\hline \multirow[t]{2}{*}{$20 \%$} & $3611.43 \mathrm{a}$ & $1,172.00$ & 729.63 & 4.95 \\
\hline & \multicolumn{4}{|c|}{ Enzymes } \\
\hline Absence & $3495.07 \mathrm{~b}$ & $1,171.39$ & 730.87 & $4.83 \mathrm{~b}$ \\
\hline Presence & $3653.69 \mathrm{a}$ & $1,178.83$ & 723.75 & $5.00 \mathrm{a}$ \\
\hline Anova $(\mathrm{p}<0.05)$ & \multicolumn{4}{|c|}{ p-value } \\
\hline Ration & 0.0001 & 0.5849 & 0.6746 & 0.0001 \\
\hline Level & 0.0221 & 0.2984 & 0.4465 & 0.0791 \\
\hline Enzymes & 0.0001 & 0.2161 & 0.2495 & 0.0002 \\
\hline Level $\times$ enzymes & 0.9322 & 0.3426 & 0.1595 & 0.1368 \\
\hline
\end{tabular}

Pesq. agropec. bras., Brasília, v.54, e00983, 2019 DOI: 10.1590/S1678-3921.pab2019.v54.00983 
Regarding the sexual maturity of the chickens, egg production started at approximately 126 days of age, i.e., at 17 weeks (Table 4), which is consistent with the Management Guide (Hy-Line International, 2016) for the line. Furthermore, the inclusion of SC or enzymes did not affect the age of sexual maturity of the pullets.

The performance variables analyzed at the beginning of the productive cycle were not influenced by the treatments. There were no interactions in the laying phase up to 35 weeks of age (Table 4). However, there was an increase in the feed intake of the birds with the addition of enzymes in the ration. Araujo et al. (2008) studied the residual effect of the inclusion of wheat bran and enzymes in the rations of 15-week-old pullets on feed consumption, egg weight, and specific gravity. The authors found that the birds that had received diets based on corn and soybean meal during the rearing phase showed an improved initial weight in the laying phase when the enzymatic complex was added.
The egg quality results are the expected for the phase (Table 5) according to the Management Guide (Hy-Line International, 2016). A significant interaction was observed in relation to the specific density of eggs, which decreased with an increase in SC in the rations and no enzyme addition.

The higher inclusion level of SC may have worsened the specific density of eggs due to the presence of fiber and ethereal extract in this ingredient, which may have caused a negative effect on calcium absorption, impairing egg shell quality (Rath et al., 2000; Muramatsu et al., 2005). The inclusion of enzymes also affected the specific density of eggs, which may be related to the reduction in the nutritional matrix of these rations, in which the enzymes were not efficient for the birds to make good use of the nutrients and to maintain egg quality.

Regarding the isolated effect of the SC inclusion level, the Haugh unit values were worse for the birds subjected to the treatments containing $20 \% \mathrm{SC}$ in the

Table 4. Performance of 18-to-35-week-old Hy-line W-36 layers fed with ration with or without the inclusion of sunflower (SC) cake and the addition of enzymes (ENZ) during the total growth period from 7 to 17 weeks of age ${ }^{(1)}$.

\begin{tabular}{|c|c|c|c|c|c|c|}
\hline \multirow[t]{2}{*}{ Ration } & \multicolumn{6}{|c|}{ Variables $^{(2)}$} \\
\hline & FE (days) & $\mathrm{FC}(\mathrm{g})$ & $\mathrm{EW}(\mathrm{g})$ & Laying (\%) & $\begin{array}{l}\text { EM (gram per } \\
\text { bird per day) }\end{array}$ & $\mathrm{FC}\left(\mathrm{g} \mathrm{g}^{-1}\right)$ \\
\hline $0 \% \mathrm{SC}$ & 125.83 & 80.18 & 54.00 & 92.70 & 50.11 & 1.60 \\
\hline $10 \% \mathrm{SC}$ & 126.50 & 80.64 & 53.95 & 93.33 & 50.37 & 1.60 \\
\hline $20 \% \mathrm{SC}$ & 125.83 & 80.44 & 53.68 & 93.54 & 50.22 & 1.60 \\
\hline $10 \% \mathrm{SC}+\mathrm{ENZ}$ & 127.00 & 81.41 & 54.14 & 93.58 & 50.69 & 1.61 \\
\hline $20 \% \mathrm{SC}+\mathrm{ENZ}$ & 126.67 & 82.08 & 53.50 & 93.67 & 50.17 & 1.64 \\
\hline Average & 126.37 & 80.95 & 53.86 & 93.37 & 50.32 & 1.61 \\
\hline \multirow[t]{2}{*}{ CV (\%) } & 11.34 & 1.59 & 1.32 & 1.30 & 1.66 & 1.74 \\
\hline & \multicolumn{6}{|c|}{ Level } \\
\hline $10 \%$ & 126.75 & 81.02 & 54.04 & 93.46 & 50.53 & 1.60 \\
\hline \multirow[t]{2}{*}{$20 \%$} & 126.25 & 81.26 & 53.59 & 93.60 & 50.19 & 1.62 \\
\hline & \multicolumn{6}{|c|}{ Enzymes } \\
\hline Absence & 126.17 & $80.54 \mathrm{~b}$ & 53.81 & 93.43 & 50.30 & 1.60 \\
\hline Presence & 126.83 & $81.74 \mathrm{a}$ & 53.82 & 93.68 & 50.43 & 1.62 \\
\hline Anova $(\mathrm{p}<0.05)$ & \multicolumn{6}{|c|}{$\mathrm{p}$-value } \\
\hline Ration & 0.9845 & 0.0991 & 0.5284 & 0.6487 & 0.7549 & 0.1543 \\
\hline Level & 0.7449 & 0.6448 & 0.1612 & 0.7495 & 0.3123 & 0.1952 \\
\hline Enzymes & 0.6648 & 0.0284 & 0.9958 & 0.6780 & 0.6850 & 0.0891 \\
\hline Level $\times$ enzymes & 0.9135 & 0.4013 & 0.5503 & 0.9048 & 0.5723 & 0.1952 \\
\hline
\end{tabular}

${ }^{(1)}$ Means followed by equal letters, in the columns, do not differ by the F-test, at $5 \%$ probability. ${ }^{(2)} \mathrm{FE}$, average age at first egg in days; FC, feed consumption; EW, egg weight; EM, egg mass; and FC, food conversion. 
rations (Table 5). This was attributed to the decrease in the use of nutrients with the inclusion of this ingredient, which has a high level of insoluble fiber, not providing the necessary nutritional support for the birds to produce quality albumen. Moreover, the presence of chlorogenic acid in this ingredient can affect the quality of protein in several ways, by, for instance, reducing its digestibility (Prigent et al., 2003).

Pinheiro et al. (2013) evaluated the effects of the inclusion of $0,7,14$, and $21 \% \mathrm{SC}$ in the feed of semiweighted laying hens up to 46 weeks of age and also found a significant effect of treatments on Haugh units, which worsened with the inclusion of $21 \%$ SC in the feed.

The values of the costs were obtained from the experimental rations provided in the growth phase from 7 to 17 weeks of age, according to kilogram of

Table 5. Egg quality and components of Hy-Line W-36 laying hens fed with ration with or without the inclusion of sunflower cake (SC) and the addition of enzymes (ENZ) in the total growth phase from 7 to 17 weeks of age ${ }^{(1)}$.

\begin{tabular}{lcccccc}
\hline Ration & \multicolumn{6}{c}{ Variables $^{(2)}$} \\
\cline { 2 - 7 } & $\begin{array}{c}\text { SD } \\
\left(\mathrm{g} \mathrm{cm}^{-3}\right)\end{array}$ & HU & $\begin{array}{c}\text { Albumen } \\
(\%)\end{array}$ & $\begin{array}{c}\text { Yolk } \\
(\%)\end{array}$ & $\begin{array}{c}\text { Eggshell } \\
(\%)\end{array}$ & $\begin{array}{c}\text { ST } \\
(\mathrm{mm})\end{array}$ \\
\hline $0 \% \mathrm{SC}$ & 1.093 & 97.26 & 67.87 & 22.42 & 9.71 & 0.42 \\
$10 \% \mathrm{SC}$ & 1.092 & 97.94 & 67.84 & 22.39 & 9.77 & 0.42 \\
$20 \% \mathrm{SC}$ & $1.088^{*}$ & 96.56 & 67.69 & 22.55 & 9.76 & 0.43 \\
$10 \% \mathrm{SC}+\mathrm{ENZ}$ & $1.088^{*}$ & 97.78 & 67.89 & 22.41 & 9.70 & 0.42 \\
20\% SC+ENZ & $1.089^{*}$ & 96.81 & 67.60 & 22.62 & 9.78 & 0.43 \\
Average & 1.090 & 97.27 & 67.78 & 22.48 & 9.74 & 0.42 \\
CV (\%) & 0.150 & 1.27 & 0.41 & 1.24 & 1.45 & 1.63 \\
\hline & & \multicolumn{5}{c}{ Level } \\
10\% & 1.089 & $97.86 \mathrm{a}$ & 67.86 & 22.40 & 9.73 & 0.42 \\
20\% & 1.088 & $96.69 \mathrm{~b}$ & 67.65 & 22.58 & 9.77 & 0.43 \\
\hline & & \multicolumn{5}{c}{ Enzymes } \\
Absence & $1.090 \mathrm{a}$ & 97.25 & 67.76 & 22.47 & 9.76 & 0.42 \\
Presence & $1.088 \mathrm{~b}$ & 97.29 & 67.75 & 22.52 & 9.74 & 0.42 \\
\hline Anova (p<0.05) & & \multicolumn{5}{c}{$\mathrm{p}-\mathrm{value}$} \\
Ration & 0.0001 & 0.2640 & 0.3349 & 0.5617 & 0.8222 & 0.0880 \\
Level & 0.1311 & 0.0458 & 0.0701 & 0.1534 & 0.5739 & 0.0064 \\
Enzymes & 0.0194 & 0.9356 & 0.8898 & 0.7133 & 0.6753 & 1.0000 \\
Level x enzymes & 0.0007 & 0.7156 & 0.5371 & 0.8462 & 0.4296 & 0.5497 \\
\hline
\end{tabular}

${ }^{(1)}$ Means followed by equal letters, in columns, do not differ by the F-test, at $5 \%$ probability. ${ }^{(2)} \mathrm{SD}$, specific density; HU, Haugh unit; and ST, shell thickness. *Significant by Dunnett's test, at 5\% probability. body weight gain (Table 6). Furthermore, there was no significant interaction and no isolated effect of the evaluated factors on economic viability. The rations that presented lower cost per kilogram of body weight gain and better results for the economic efficiency index and cost index were those with $20 \%$ SC with enzymes, followed by rations with only $20 \% \mathrm{SC}$, and rations containing $10 \% \mathrm{SC}$ with enzymes, all compared, in isolation, with the control diet (Table 6).

The treatment with the inclusion of $20 \%$ SC with the addition of enzymes reduced the feed cost per kilogram of body weight gain in $\mathrm{R} \$ 0.35$, improving the cost index by $5.16 \%$. This improvement in economic viability may be associated with a reduction in the quantity of traditional ingredients, which occurred when $20 \%$ SC and enzymes were included in the rations, reducing their costs.

Table 6. Average feed cost per kilogram of body weight gain, economic efficiency index (EEI), and cost index (CI) according to the inclusion levels of sunflower cake (SC) and the addition of enzymes (ENZ) in the ration for Hy-Line $\mathrm{W}-36$ chickens in the total growth phase from 7 to 17 weeks of age.

\begin{tabular}{|c|c|c|c|}
\hline \multirow[t]{2}{*}{ Ration } & \multicolumn{3}{|c|}{ Variables } \\
\hline & $\begin{array}{l}\text { Cost ( } \mathrm{R} \$ \mathrm{~kg}^{-1} \\
\text { weight gain) }\end{array}$ & EEI (\%) & CI (\%) \\
\hline $0 \% \mathrm{SC}$ & 6.97 & 95.00 & 105.16 \\
\hline $10 \% \mathrm{SC}$ & 6.81 & 97.33 & 102.66 \\
\hline $20 \% \mathrm{SC}$ & $6.69^{*}$ & $99.33 *$ & $100.66^{*}$ \\
\hline $10 \% \mathrm{SC}+\mathrm{ENZ}$ & $6.70^{*}$ & $98.83 *$ & $101.16^{*}$ \\
\hline $20 \% \mathrm{SC}+\mathrm{ENZ}$ & $6.62 *$ & $100.00 *$ & $100.00 *$ \\
\hline Average & 6.76 & 98.10 & 101.93 \\
\hline \multirow[t]{2}{*}{ CV (\%) } & 1.99 & 2.13 & 2.11 \\
\hline & \multicolumn{3}{|c|}{ Level } \\
\hline $10 \%$ & 6.76 & 98.08 & 101.91 \\
\hline \multirow[t]{2}{*}{$20 \%$} & 6.66 & 99.67 & 100.33 \\
\hline & \multicolumn{3}{|c|}{ Enzymes } \\
\hline Absence & 6.75 & 98.33 & 101.67 \\
\hline Presence & 6.66 & 99.41 & 100.58 \\
\hline Anova $(\mathrm{p}<0.05)$ & \multicolumn{3}{|c|}{ p-value } \\
\hline Ration & 0.0015 & 0.0027 & 0.0027 \\
\hline Level & 0.0510 & 0.0659 & 0.0659 \\
\hline Enzymes & 0.1021 & 0.1982 & 0.1982 \\
\hline Level $\mathrm{x}$ enzymes & 0.6039 & 0.6143 & 0.6143 \\
\hline
\end{tabular}

*Significant by Dunnett's test, at 5\% probability. 


\section{Conclusions}

1. The inclusion of up to $20 \%$ sunflower (Helianthus annuus) cake in rations for lightweight replacement pullets does not affect performance in the growth and laying phases, but the use of $20 \%$ sunflower cake with enzymes is more economically viable.

2. The inclusion of $20 \%$ sunflower cake in the rations for lightweight replacement pullets, with or without enzymes, does not interfere with the age for the first egg, although it worsens the specific density of the eggs.

\section{References}

ANDRADE, T.V. de; SANTOS, R.N.V.; ARAÚJO, D.J.; BRAULINO, D. de S.; MOURA, M.V.B.T.P. de; BORGES, L. da $\mathrm{S}$. Efeito de fatores antinutricionais encontrados nos alimentos alternativos e seu impacto na alimentação de não ruminantes revisão. Revista Eletrônica Nutritime, v.12, p.4393-4399, 2015.

ARAUJO, D. de M.; SILVA, J.H.V. da; ARAUJO, J.A. de; RIBEIRO, M.L.G.; PASCOAL, L.A.F.; COSTA, F.G.P. Farelo de trigo e complexo enzimático na alimentação de frangas de reposição. Ciência e Agrotecnologia, v.32, p.1960-1967, 2008. DOI: https://doi.org/10.1590/S1413-70542008000600040.

ARRUDA, A.M.V. de; FERNANDES, R.T.V.; SILVA. S.L.G. da; MELO, A. da S.; FERNANDES, D.R.; DANTAS, F.D.T.; FILGUEIRA, T.M.B. Alimentos alternativos para aves Isa Label no Rio Grande do Norte - Brasil. Revista Centauro, v.7, p.17-33, 2016.

BACAXIXI, P.; RODRIGUES, L.R.; BUENO, C.E.M.S.; RICARDO, H.A.; EPIPHANIO, P.D.; SILVA, D.P.; BARROS, B.M.C.; SILVA, T.F. Teste de germinação de girassol Helianthus annuus L. Revista Científica Eletrônica de Agronomia, ano 10, 2011.

BARBOSA, N.A.A.; BONATO, M.A.; SAKOMURA, N.K.; DOURADO, L.R.B.; FERNANDES, J.B.K.; KAWAUCHI, I.M. Digestibilidade ileal de frangos de corte alimentados com dietas suplementadas com enzimas exógenas. Comunicata Scientiae, v.5, p.361-369, 2014. DOI: https://doi.org/10.14295/CS.V5I4.460.

BELLAVER, C.; FIALHO, E.T.; PROTAS, J.F. da S.; GOMES, P.C. Radícula de malte na alimentação de suínos em crescimento e terminação. Pesquisa Agropecuária Brasileira, v.20, p.969-974, 1985.

BERWANGER, E.; NUNES, R.V.; POZZA, P.C.; OLIVEIRA, T.M.M. de; SCHERER, C.; FRANK, R.; BAYERLE, D.F.; HENZ, J.R. Nutritional and energy values of sunflower cake for broilers. Semina: Ciências Agrárias, v.35, p.3429-3438, 2014. DOI: https://doi.org/10.5433/1679-0359.2014v35n6p3429.

BRAZ, N. de M.; FREITAS, E.R.; BEZERRA, R.M.; CRUZ, C.E.B.; FARIAS, N.N.P.; SILVA, N.M. da; SÁ, N.L.; XAVIER, R.P. de S. Fibra na ração de crescimento e seus efeitos no desempenho de poedeiras nas fases de crescimento e postura.
Revista Brasileira de Zootecnia, v.40, p.2744-2753, 2011. DOI: https://doi.org/10.1590/S1516-35982011001200019.

FEDNA. Fundación Española para el Desarrollo de la Nutrición Animal. Ingredientes para piensos (Tablas FEDNA 2010). 2010. Available at: $<$ http://www.fundacionfedna.org/ingredientes-parapiensos>. Accessed on: May 232019.

FIALHO, E.T.; BARBOSA, H.P.; FERREIRA, A.S.; GOMES, P.C.; GIROTTO, A.F. Utilização da cevada em dietas suplementadas com óleo de soja para suínos em crescimento e terminação. Pesquisa Agropecuária Brasileira, v.27, p.1467$1475,1992$.

HY-LINE INTERNATIONAL. Guia de manejo Hy-Line W36. Poedeiras comerciais W-36. 2016. 44p. Available at: <https:// www.hyline.com/userdocs/pages/36_COM_POR.pdf $>$. Accessed on: May 232019.

JACOB, J.P.; MITARU, B.N.; MBUGUA, P.N.; BLAIR, $R$. The feeding value of Kenyan sorghum, sunflower seed cake and sesame seed cake for broilers and layers. Animal Feed Science and Technology, v.61, p.41-56, 1996. DOI: https://doi.org/10.1016/0377-8401(96)00957-1.

KALMENDAL, R.; ELWINGER, K.; HOLM, L.; TAUSON, R. High-fibre sunflower cake affects small intestinal digestion and health in broiler chickens. British Poultry Science, v.52, p.86-96, 2011. DOI: https://doi.org/10.1080/00071668.2010.547843.

MURAMATSU, K.; STRINGHINI, J.H.; CAFÉ, M.B.; JARDIM FILHO, R. de M.; ANDRADE, L.; GODOI, F. Desempenho, qualidade e composição de ácidos graxos do ovo de poedeiras comerciais alimentadas com rações formuladas com milho ou milheto contendo diferentes níveis de óleo vegetal. Acta Scientiarum. Animal Sciences, v.27, p.43-48, 2005. DOI: https://doi.org/10.4025/actascianimsci.v27i1.1257.

OLIVEIRA, D.D. de; PINHEIRO, J.W.; FONSECA, N.A.N.; OBA, A. Desempenho de frangos de corte alimentados com torta de girassol. Semina: Ciências Agrárias, v.33, p.1979-1990, 2012. DOI: https://doi.org/10.5433/1679-0359.2012v33n5p1979.

OLIVEIRA, T.M.M. de; NUNES, R.V.; MARCATO, S.M.; BERWANGER, E.; BAYERLE, D.F.; SCHÖNE, R.A.; FRANK, R.; SANGALI, C.P. Farelo de girassol para aves: composição química e alterações metodológicas na determinação dos valores energéticos e de aminoácidos digestíveis. Semina: Ciências Agrárias, v.35, p.3415-3428, 2014. DOI: https://doi.org/10.5433/1679-0359.2014v35n6p3415.

OPALINSKI, M.; MAIORKA, A.; CUNHA, F. da; ROCHA, C. da; BORGES, S.A. Adição de complexo enzimático e da granulometria da soja integral desativada melhora desempenho de frangos de corte. Ciência Rural, v.40, p.628-632, 2010. DOI: https://doi.org/10.1590/S0103-84782010005000017.

PEREIRA, E.S.; PIMENTEL, P.G.; BOMFIM, M.A.D.; CARNEIRO, M.S. de S.; CÂNDIDO, M.J.D. Torta de girassol em rações de vacas em lactação: produção microbiana, produção, composição e perfil de ácidos graxos do leite. Acta Scientiarum. Animal Sciences, v.33, p.387-394, 2011. DOI: https://doi.org/10.4025/actascianimsci.v33i4.11327.

PINHEIRO, J.W.; FONSECA, N.A.N.; SILVA, C.A. da; OBA, A.; BALARIN, M.R.S.; BRUNELLI, S.R. Torta de 
girassol na alimentação de poedeiras semipesadas. Semina:

Ciências Agrárias, v.34, p.3959-3970, 2013. Supl.2. DOI: https://doi.org/10.5433/1679-0359.2013v34n6Supl2p3959.

PRIGENT, S.V.E.; GRUPPEN, H.; VISSER, A.J.W.G.; VAN KONINGSVELD, G.A.; JONG, G.A.H. de; VORAGEN, A.G.J. Effects of non-covalent interactions with 5-O-caffeoylquinic acid (chlorogenic acid) on the heat denaturation and solubility of globular proteins. Journal of Agricultural and Food Chemistry, v.51, p.5088-5095, 2003. DOI: https://doi.org/10.1021/jf021229w.
RATH, N.C.; HUFF, G.R.; HUFF, W.E.; BALOG, J.M. Factors regulating bone maturity and strength in poultry. Poultry Science, v.79, p.1024-1032, 2000. DOI: https://doi.org/10.1093/ps/79.7.1024.

ROSTAGNO, H.S. (Ed.). Tabelas brasileiras para aves e suínos: composição de alimentos e exigências nutricionais. 4.ed. Viçosa: Ed. da UFV, 2017. 488p.

SAKOMURA, N.K.; ROSTAGNO, H.S. Métodos de pesquisa em nutrição de monogástricos. Jaboticabal: FUNEP, 2007. $283 p$.

SILVA, D.J.; QUEIROZ, A.C. de. Análise de alimentos: métodos químicos e biológicos. 3.ed. Viçosa: UFV, 2002. 235p. 